\title{
Analysis of Scientific Research Related Anxiety Levels of Undergraduate Students'
}

\author{
Sefa Yildirim ${ }^{1, *}$, Mehmet Akif Haşıloğlu² \\ ${ }^{1}$ History Department, the Faculty of Art and Science, A ğrı İbrahim Çeçen University, Ağrı, Turkey \\ ${ }^{2}$ The Faculty of Education, Ağrı İbrahim Çeçen University, Ağrı, Turkey
}

Copyright $\odot 2018$ by authors, all rights reserved. Authors agree that this article remains permanently open access under the terms of the Creative Commons Attribution License 4.0 International License

\begin{abstract}
In this study, it was aimed to identify the scientific research-related anxiety levels of the undergraduate students studying in the department of faculty of science and letters and faculty of education to analyse these anxiety levels in terms of various variables (students' gender, using web based information sources, going to the library, studying department, taking a course related to measurement and evaluation during undergraduate education), considering foregoing knowledge. This descriptive study was done using relational screening model from screening models. The sample of the research consisted of 534 students studying at Faculty of Education and Faculty of Science and Letters of Ağrı İbrahim Çeçen University located in the east of Turkey, during the Fall Semester of 2017-2018. Participants consisted of 314 females and 220 males. 208 of the participants study at Department of History, 34 of those at Department of Science, 45 of those at Department of Geography, 120 of those at Turkish Philology, and 127 of those at Department of Computer and Instructional Technologies Training. The data were attained through the "Personal Information Form" created by the researchers, and "Research-Related Anxiety Scale" developed by Büyukozturk [2]. As a result of the analysis made, no significant relationship was found between students' research-related anxiety levels and the variables such as students' gender, studying department, taking a course related to measurement and evaluation during undergraduate education. But, a significant relationship was found between students' research-related anxiety levels and the variables such as using web based information sources, going to the library. It was determined that undergraduate students' habits of going to the library and using web based information sources significantly reduced research anxiety.
\end{abstract}

Keywords History Education, Science Education, Scientific Research Anxiety Level, Web and Library

\section{Introduction}

When history and science education researches are examined in Turkey, we see that the researches in this area have been conducted as theoretical studies based on literature for a long time. These studies, not so much in number, have been mostly focused on the importance of history and science education, and on why and how they should be taught [8].

When compared to two decades ago, it is seen that a significant literature has been created in the field of history and science education in our country, and significant studies have been conducted in the different dimensions of the field. On the other hand, there is not enough study in Turkey regarding what these studies are, and their evaluation [6]. As well as there are many reasons of the insufficiency of these studies, one of its most important reasons may be that university students insufficiently receive scientific research and application courses.

As is known, one of the two main functions of the universities is conduct education and training, and the other one is to do research. As well as the necessity of appropriate research environment to sustain research activities, it is also important and necessary for individuals and institutions that will conduct research, to have research competencies and positive attitudes that enable them to make the research. Providing students to gain research culture is an educational issue. Research education aims to create scientific consciousness in individuals and societies by gaining them scientific attitudes and behaviors, and qualifications related to research field [9]. This education aims at acquiring the knowledge and skills and scientific attitudes and behaviors necessary for conducting research or making effective use of researches. Research competencies can be considered as a component of research techniques, statistics, measurement-evaluation and computer information fields [4]. Research culture, considered as one of the basic characteristics of contemporary society, includes cognitive, affective, and psychomotor competence or qualifications, and it is 
accepted that it can be gained to individuals by education. The acquisition of research knowledge and skill is an essential condition for the individual to be able to do research; but it's not enough. The interest of the individual in this field, his/her own morals, and whether he/she sees this process as a threat for himself/herself are effective factors for him/her to do research $[11,2]$. However, as well as there is an important consensus on the necessity of doing research at the undergraduate and graduate level in the universities in Turkey, Karasar [10] revealed through a research finding that the education given is not as sufficient as for that.

\section{Method}

\subsection{Research Model}

This descriptive study was conducted using the relational screening model from screening models. Relational screening models aim to determine the presence and / or extent of change between two or more variables [11].

\subsection{Data Analysis}

A statistic program was used to analyze the data. The data from data collection tools were analyzed using descriptive statistics (frequency, arithmetic mean). Besides, t-test and one-way analysis of variance (ANOVA) analysis techniques were used for independent groups [5].

\subsection{Universe-sample}

The sample of the research consisted of 534 students studying at Faculty of Education and Faculty of Science and Letters of Agrı Ibrahim Cecen University located in the east of Turkey, during the Fall Semester of 2017-2018. Participants consisted of 314 females and 220 male. 208 of the participants study at Department of History, 34 of those at Department of Science, 45 of those at Department of Geography, 120 of those at Turkish Philology, 127 of those at Department of Computer and Instructional Technologies Training.

\subsection{Data Collection Tool}

"Personal Information Form" prepared by researchers and "Research Anxiety Scale" developed by Büyüköztürk [2] were used as data collection tool in the research. Personal information form contains questions regarding gender, using web based information sources, going to the library, studying department, taking a course related to measurement during undergraduate education. The "Research Anxiety Scale" which was developed by Büyüköztürk [2] on university students is a scale in the type of five point Likert Scale (1-I never agree, 2-I disagree, 3- I am undecided, 4- I agree, 5-I completely agree), consisting of 12 items gathered under one factor, and has a responding format. Five items $(2,3,4,8$ and 11) in the scale consists of positive statements (not expressing anxiety), seven items $(1,5,6,7,9,10,12)$ consists of negative statements (expressing anxiety), and negative items were encoded as reverse. By this way, the high score gotten from the scale means that the research anxiety is low. The Cronbach-Alpha internal consistency coefficient of the scale is $\alpha=.87$ [2]. Thus, the high score from the scale indicates that the person is anxious to do research, while the low score indicates that the person is less anxious. At least 12 points and a maximum of 60 points can be gotten from the scale. Since the original form of this Research Awareness Scale was developed on undergraduate students, the evidence of validity and reliability was not reproduced. Since the original form of this Research Awareness Scale was developed on undergraduate students, the evidence of validity and reliability was not reproduced.

\section{Purpose of Study}

In this study, it was aimed to identify the scientific research-related anxiety levels of the undergraduate students studying in the department of faculty of science and letters and faculty of education to analyse these anxiety levels in terms of various variables (students' gender, using web based information sources, going to the library, studying department, taking a course related to measurement and evaluation during undergraduate education), considering foregoing knowledge.

\section{Findings and Comments}

Table 1. t-Test Results According to Gender Variable

\begin{tabular}{|c|c|c|c|c|c|}
\hline & Gender & $\mathbf{N}$ & $\bar{X}$ & $\mathbf{t}$ & P \\
\hline \multirow{2}{*}{ Research Anxiety Levels } & Female & 314 & 45.53 & \multirow{2}{*}{2.022} & \multirow{2}{*}{$.04 *$} \\
\cline { 2 - 5 } & Male & 220 & 44.03 & & \\
\hline
\end{tabular}

${ }^{*} \mathrm{p}<.05$

When Table 1 is examined, it is seen that the average score of female students is higher than male students. The increase in the score from the scale is inversely proportional to the decrease in students' research concerns. Besides, The results of $t$ test conducted for independent groups to determine the changes by gender variable showed that there is a significant difference in favor of females in terms of students' average of total scores $(t=2.022, p<.05)$. When the average scores are compared in terms of gender, it appears that there is a significant result in favor of females. That is, females' levels of research anxiety is lower than male's. 
Table 2. t-Test Results According to a Course Taking Variable Related to Measurement and Evaluation

\begin{tabular}{|c|c|c|c|c|c|}
\hline & Taking Course & $\mathbf{N}$ & $\bar{X}$ & $\mathbf{t}$ & $\mathbf{P}$ \\
\hline $\begin{array}{c}\text { Research Anxiety } \\
\text { Levels }\end{array}$ & Yes & 226 & 45.46 & \multirow{2}{*}{1.339} & $.162 *$ \\
\cline { 2 - 5 } & No & 302 & 44.43 & & \\
\hline
\end{tabular}

$* \mathrm{p}>.05$

When Table 2 is examined, it is seen that there is no significant difference between undergraduate students who did not take course related to measurement and evaluation, and those who took course related to measurement and evaluation, in terms of research concerns. The results of $t$ test conducted for independent groups to determine the changes by taking course variable showed that there is not a significant difference between the "research anxiety levels" related average scores of undergraduate students and the undergraduates, not taking course according to variable related to measurement and evaluation $(t=1.339$, $\mathrm{p}>.05)$.

Table 3. t-Test Results according to the condition of going to library adequately during the undergraduate education

\begin{tabular}{|c|c|c|c|c|c|}
\hline & Going to library & N & $\bar{X}$ & t & P \\
\hline \multirow{2}{*}{$\begin{array}{c}\text { Research Anxiety } \\
\text { Levels }\end{array}$} & Yes & 204 & 46.40 & \multirow{2}{*}{3.226} & \multirow{2}{*}{$.001^{*}$} \\
\cline { 2 - 4 } & No & 327 & 44.01 & & \\
\hline
\end{tabular}

$* \mathrm{p}<.05$

When Table 3 is examined, it is seen that there is a significant difference in favor of those who go to the library during the undergraduate education $(\bar{X}=46.40)$ and those who don't go ( $\bar{X}=44.01)$, in terms of going to library adequately. Since the rise in the score taken from the scale caused research anxiety to decrease, those who go to the library experience less anxious than those who do not. $(\mathrm{t}=$ $3.226, \mathrm{p}<.05)$.

Table 4. t-Test Results according to the use of web-based information sources during the undergraduate education

\begin{tabular}{|c|c|c|c|c|c|}
\hline & $\begin{array}{c}\text { Web-based } \\
\text { information sources }\end{array}$ & $\mathbf{N}$ & $\bar{X}$ & $\mathbf{t}$ & $\mathbf{P}$ \\
\hline \multirow{2}{*}{$\begin{array}{c}\text { Research Anxiety } \\
\text { Levels }\end{array}$} & Yes & 263 & 47.06 & \multirow{2}{*}{3.226} & .001 \\
\cline { 2 - 6 } & No & 266 & 42.72 & & \\
\hline
\end{tabular}

When Table 4 is examined, it is seen that there is a significant difference in favor of those who use web-based information sources. $(\mathrm{t}=3.226, \mathrm{p}<.05)$. In other words, it can be said that those who use web-based information sources $(\bar{X}=47.06)$ have lower anxiety than those who do $\operatorname{not}(\bar{X}=42.72)$

Table 5. Comparison of research anxiety levels according to undergraduate education - Anova test

\begin{tabular}{|c|c|c|c|c|}
\hline Departments & $\mathrm{N}$ & $\bar{X}$ & $\mathrm{f}$ & $\mathrm{P}$ \\
\hline Department of Geography & 45 & 45,4 & & \\
\hline Department of Science Education & 34 & 44,3824 & 1,137 & 0,338 \\
\hline Department of History & 208 & 44,024 & & \\
\hline $\begin{array}{c}\text { Department of Turkish language and } \\
\text { literature }\end{array}$ & 120 & 45,8083 & & \\
\hline $\begin{array}{c}\text { Department of Computer and } \\
\text { Instructional Technologies Education }\end{array}$ & 127 & 45,4488 & & \\
\hline
\end{tabular}

The mean anxiety scores were compared according to studying departments, but no significant difference was found between them ( $\mathrm{f}=1.137, \mathrm{p}<.05$ ). When the averages of the undergraduate students were examined, it was observed that the students studying in the Turkish Language and Literature department $(\bar{X}=45.80)$ had higher research anxiety levels than the other departments' students. But, the other departments were compared between each other, no statistically significant difference was determined.

\section{Discussion and Conclusions}

In this study, it was aimed to identify the scientific research-related anxiety levels of the undergraduate students studying in the department of faculty of science and letters and faculty of education to analyse these anxiety levels in terms of various variables (studens' gender, using web based information sources, going to the library, studying department, taking a course related to measurement and evaluation during undergraduate education), considering foregoing knowledge. In this study, no significant difference was found in students' scientific research related anxiety levels in terms of gender variable. This conclusion matches with the findings of the study that Eğmir at al. [7] conducted on graduate students. According to the study findings of Saracaloğlu at al. [13], Saracaloğlu [12], Bökeoğlu and Yılmaz [1], Büyüköztürk [3] and Yılmaz and Çokluk [14]; research anxiety scores of students do not change according to gender variable. In this context, it can be said that the related researches support each other. However, according to the results of the research by [9] it was found that students' scientific research-related anxiety levels significantly differ according to the gender variable and male students have higher scientific research-related anxiety levels than female students. This result does not match with the result we have found. Another result of this research is that there is no significant difference in favor of the students' studying department (History, Science Education, Turkish Language and Literature, Geography, Computer and Instructional Technologies Education Department).

According to the findings of this research, there is no significant difference between the students' taking course of previous scientific research methods and their scientific research-related anxiety levels. In other words, whether or not students have taken a course on scientific research methods does not significantly affect their level of anxiety about doing scientific research. According to this result, the reason why students did not reach desired success in these courses due to high level of anxiety may be the lackness of enough practical courses for these courses. This finding is consistent with the findings of the study by [7] on graduate students. However, according to research findings of Saracaloğlu at al. [13], students' scientific research- related 
anxiety differs by their "level of graduate education". In addition, [9] found a statistically significant difference, in favor of research assistants, between the research anxiety scores of the students who were research assistant and those who were not research assistant. According to the results of the study by Büyüköztürk [2]; graduate students have less research anxiety than undergraduate students. This may be due to the fact that the graduate students and the research assistants took more practice oriented courses from among scientific research methods- related courses.

According to another result of the study, since the higher the score from the scale the lower the research anxiety level, those who go to the library experience less anxious than those who do not. $(t=3.226, p<.05)$. As it is seen from this result, getting individuals adopt the habit of making use of the library, which is an important factor in teaching individuals thinking scientifically, criticising, socially conscious, is closely related to the applied education. Because the concepts such as scientific thinking, criticising, research consciousness gaining are the main objectives of education. Accordingly, these and similar virtues are improved in direct proportion to reading habit. Accordingly, students' web based information sources using during the undergraduate education was measured in the scale, and it was seen that a significant result is obtained in favor of those who use web based information sources during the undergraduate education $(\mathrm{t}=3.226, \mathrm{p}<.05)$. In other words, it can be said that those who use web based information sources $(\bar{X}=$ 47.06) undergo less anxiety than those who do not use ( $\bar{X}$ $=42.72$ ). It was seen as a result of this study which aimed to determine the reasons why undergraduate students experience anxiety for doing research that especially students' attaching importance to the use of web-based information resources during their undergraduate education and more often going to the library positively affected their research anxiety levels. It was concluded that undergraduate students should attach importance to the use of web-based information resources during their undergraduate education, and they should be encouraged on going to the library more often.

\section{REFERENCES}

[1] Bökeoğlu, Ç. and Yılmaz, K. (2005). Üniversite Öğrencilerinin Eleştirel Düşünmeye Yönelik Tutumları ile Araştırma Kaygıları Arasındaki İlişki. Kuram ve
Uygulamada Eğitim Yönetimi, 41, 47-67.

[2] Büyüköztürk, S. (1997). Araştırmaya Yönelik Kayg1 Ölçeğinin Geliştirilmesi. Eğitim Yönetimi Dergisi, 4, 453-464.

[3] Büyüköztürk S. (1999). Araștırmaya Yönelik Kayg1 ile Cinsiyet Araştırma Deneyimi ve Araştırma Başarısı Arasındaki İlişki. Eğitim ve Bilim, 23(112), 29-34.

[4] Büyüköztürk, Ş. \& Köklü, N. (1999). Eğitim Bilimleri Alanında Öğrenim Gören Lisansüstü Öğrencilerinin Araştırma Yeterlikleri Konusunda Öğretim Üyelerinin Görüşleri. Eğitim ve Bilim, 23(112), 18-28.

[5] Büyüköztürk, Ș, Çakmak, E.K., Akgün, Ö.E.,Karadeniz, Ș. and Demirel, F. (2008). Bilimsel Araştırma Yöntemleri, Ankara: PegemA Akademi Yayınları.

[6] Demir, R. (2008). Üniversitelerin Bugünü ve Yarıı. Ankara: Palme Yayinc1lik.

[7] Eğmir E., Ödemiş İ. S., Bayar V., Bayar, A. and Kayır G. (2013). Lisansüstü Eğitim Gören Öğrencilerin Akademik Güdülenme Düzeyleri, VI. Ulusal Lisansüstü Eğitim Sempozyumu Bildiriler Kitabı, pp. 97-103.

[8] Karadağ, E. (2009). Eğitim Bilimleri Alanında Yapılmış Doktora Tezlerinin Tematik Açıdan İncelemesi, Ahi Evran Üniversitesi Eğitim Fakültesi Dergisi, 10 (3), pp. 75-87.

[9] Karagül, S, and Aslan, C. (2016). Türkçe Eğitimi Programında Lisansüstü Öğrenim Gören Öğrencilerin Bilimsel Araştırma Yapmaya Yönelik Kayg1 Düzeyleri. Mehmet Akif Ersoy Üniversitesi Eğitim Fakültesi Dergisi, 1 (38), 201-217. Retrieved from http://dergipark.gov.tr/maeuefd/issue/24653/260762

[10] Karasar, N. (1984). Türk Üniversitelerinde Araștırma Eğitimi. Yayımlanmamış araştırma, (TUBİTAK SAYG-E-49 Projesi).

[11] Karasar, N. (1995). Bilimsel Araştırma Yöntemi (7. Basım). Ankara: 3A Araştırma Eğitim Danışmanlık Ltd.

[12] Saraçaloğlu, A. S. İ. (2008). Lisansüstü Öğrencilerin Akademik Güdülenme Düzeyleri, Araştırma Kaygıları ve Tutumları ile Araştırma Yeterlikleri Arasındaki İlişki. Yüzüncü Yıl Üniversitesi Eğitim Fakültesi Dergisi, V(II), 179-208.

[13] Saraçaloğlu, A.S., Varol, R., and Ercan İ.E. (2005). Lisansüstü Eğitim Öğrencilerinin Araştırma Kaygıları, Araştırma ve İstatistiğe Yönelik Tutumları ile Araştırma Yeterlikleri Arasındaki İlişki. Buca Eğitim Fakültesi Dergisi, 17, 187-199.

[14] Yılmaz, K. and Çokluk, Ö. (2010). Fen- Edebiyat Fakültesi Mezunlarının Araştırma Kaygı Düzeyleri. Abant İzet Baysal Üniversitesi Dergisi, 10(1), 1-9 